\title{
IAMJ
}

INTERNATIONAL

AYURVEDIC

MEDICAL JOURNAL

\section{EFFECT OF MAJJA BASTI AND BAHYA SNEHANA (PIZICHIL) IN AVASCULAR NECROSIS - A CASE REPORT}

\author{
Bunker Surendra ${ }^{1}$, Dixit Neetu ${ }^{2}$, Dash Babita ${ }^{3}$ \\ ${ }^{1}$ M.D. Scholar, P G Department of Panchakarma. \\ ${ }^{2}$ M.D. Scholar, P G Department of Panchakarma. \\ ${ }^{3}$ Lecturer, P G Department of Panchakarma. \\ Pt Khushilal Sharma Govt. (auto) Ayurveda College and Institute Bhopal, (MP), India
}

Corresponding Author: drsurendrabunker@gmail.com

\section{https://doi.org/10.46607/iamj09102021}

(Published Online: October 2021)

Open Access

(C) International Ayurvedic Medical Journal, India 2021

Article Received: 27/08//2021 - Peer Reviewed: 04/09/2021 - Accepted for Publication: 05/09/2021

\section{Check for updates}

\section{ABSTRACT}

Avascular necrosis (AVN) also called osteonecrosis or a disorder resulting from a temporary or permanent loss of blood supply or interruption of supply to the bone. AVN is found in the age of 30- 40 years mostly. Blood carries essential nutrients and oxygen to the bone. When the supply is disrupted, the bone tissue became necrosed. AVN can occur at any bone but most commonly affects the ends (epiphysis) of a long bone such as thigh region bone i.e. femur characterized by the collapse of bone, pain, bone destruction, limping off the leg, loss of function of affected bone (temporary or permanent). Modern medical science has surgical treatment modalities like Arthroplasty, hip replacement and osteotomy etc having a higher failure rate is also cost worthy and has a poor prognosis. As per Ayurveda, the cases were diagnosed as Asthimajjagata vata vikara. In the present study, two male patients one is 45 years old another is 30 years old having signs and symptoms of Avascular necrosis and Xray of bilateral hip joint showing AVN of the femoral head were taken into consideration and administered the therapy, Majja Basti, bahya snehana (pizichil) and the Shaman Kashaya i.e. Guggulu Tiktak Kashaya 20 ml BD for 15 days. 
significant relief with increasing functional femoral activities in the necrosed femoral head. Based on these case study it can be concluded that the Panchakarma treatment along with Shamana chikitsa is effective in the management of AVN of the femoral head.

Keywords: Avascular necrosis, Asthimajja gata vata vikar, Majja Basti, Pizichil.

\section{INTRODUCTION}

Avascular necrosis (AVN) also called osteonecrosis or a disorder resulting from a temporary or permanent loss of blood supply to the bone. AVN is defined as the cellular death of bone components due to interruption of blood supply. ${ }^{[1]}$ The bone structure collapse results in pain in the joints, loss of joint function, limping off the leg and long-term joint damage. AVN usually involve the epiphysis (end parts of the long bone) of femoral and humeral heads and the femoral condyle. ${ }^{[2]}$ Many patients have no earlier symptoms of AVN, as the condition worsens the affected joint might hurt only when weight is put on it. The true prevalence of the disease is difficult to ascertain, $5-18 \%$ of total patients undergoing a total hip replacement in the US. In India, it has been seen 16000 new cases of AVN every year which eventually will require a total hip replacement, surgery at some point in time. ${ }^{[3]}$

The disease AVN is aggravated by some etiological factors such as trauma, genetic factor, metabolic factor, glucocorticoid, alcoholism, gout etc that promote Hyper coagulable stats. In the early stage, AVN is not diagnosed properly from its clinical finding. MRI should be done to confirm the disease. Most modern treatment modalities include arthroplasty, femoral head graft, hip replacement, osteotomy etc have higher failure rates. Based on signs and symptoms, the AVN is more or less correlated with Asthimajjagata vata in Ayurveda. The sign and symptoms like Sandhishula, Mansa bala kshaya, Satata ruja (continuous pain) Anidra are found in Asthimajjagata vata. ${ }^{[4]}$ These symptoms were found due to vitiation of Vata in Asthi and Majja dhatu (ashrayashrayi sambandh). As it is told that Vata vyadhi is asadhya, so it became difficult for the complete recovery in an advanced stage of the disease. The treatment of AVN is cost-effective in modern medical systems also having poor prognosis, so an effort is made to evaluate the effect of Majja Basti and Bahya sneha Pizichil along with shaman Kashaya in the management of the disease.

\section{CASE REPORT}

Two patients namely A and B, 45 and 28 years respectively came in the OPD of Panchakarma dept of Pt Khushilal Sharma Govt Ayurved College and Institute Bhopal register no opd no10568 and opd no. 340 with the complaint of pain in bilateral hip joint and pain radiates towards bilateral knee joints with stiffness, restricted movement, limping gait, disturbed sleep etc. the X- rays show clearly necrosis of head of femur bone, further MRI report also shown the necrosis of bilateral hip joint (femoral head). Patient A is having a history of road accidents 5 years back. None of the patients were having a history of DM and HTN or any type of addiction such as alcoholism, tobacco etc. since the past 2 years patients' condition gradually deteriorated and the daily activities and movement hampered. Previously both patients were diagnosed with AVN of the bilateral femoral head from MRI (grade 3) and were advised for surgical intervention after they came to the Ayurvedic hospital Panchakarma department for the treatment. Ashtvidh and dashvidh pareeksha and systemic examination were done, both patients were treated on the line of management of Asthimajjagata vata vikara. ${ }^{[5]}$ The treatment regimen which is given in the Ayurvedic texts is aimed at restoring the equilibrium through correction of the underlying functional included vitiated vata dosha and dhatu kshaya. 
Table 1: Dashvidh Pareeksha

\begin{tabular}{|l|l|l|}
\hline Dashvidh pareeksha & Pt A & Pt B \\
\hline Prakruti & VP & VP \\
\hline Sara & Samyaka & Samyaka \\
\hline Samhanana & Madhyam & Avar \\
\hline Pramana & Sama & Sama \\
\hline Satmya & Samyaka & Khara \\
\hline Satva & Madhyam & Avara \\
\hline Aharashakti & Madhyam & Madhyama \\
\hline Vyayamshakti & Madhyam & Avara \\
\hline Vaya & Madhyam & Madhyam \\
\hline & & \\
\hline
\end{tabular}

Table 2: General examination

\begin{tabular}{|l|l|l|}
\hline & Pt A & Pt B \\
\hline BP & $120 / 90 \mathrm{~mm}$ of $\mathrm{Hg}$ & $130 / 80 \mathrm{~mm}$ of $\mathrm{Hg}$ \\
\hline PULSE & $82 / \mathrm{m}$ & $84 / \mathrm{m}$ \\
\hline RR & $18 / \mathrm{m}$ & $19 / \mathrm{m}$ \\
\hline TEMPERATURE & $98.5 \mathrm{~F}$ & $98.6 \mathrm{~F}$ \\
\hline SLEEP & Disturbed & Disturbed \\
\hline APPETITE & Normal & Normal \\
\hline BOWEL & Clear & Not clear \\
\hline
\end{tabular}

Table 3: Musculoskeletal examination

\begin{tabular}{|l|l|l|l|l|}
\hline TEST & \multicolumn{2}{l|}{ BEFORE TREATMENT } & \multicolumn{2}{l|}{ AFTER TREATMENT } \\
\hline SLR & Pt A & Pt B & Pt A & Pt B \\
\hline CROSS SLR & $50^{\circ}(+)$ & $40^{\circ}(+)$ & $70^{\circ}$ & $60^{\circ}$ \\
\hline REVERSE SLR & Negative & positive & Negative & Negative \\
\hline & Negative & positive & Negative & Negative \\
\hline
\end{tabular}

Intervention: The line of treatment of Asthimajja Gata Vata includes Bahya and Abhyantara Snehana (Ch.chi.28 $)^{[6]}$ so according to the treatment principal, Bahya Snehaana and Abhyanatara Snehana along with Shaman Kashaya were planned.

Table 4: Intervention

\begin{tabular}{|l|l|l|l|l|}
\hline S.N. & Treatment & Drug & Dose & Duration \\
\hline 1 & Majja basti & Majja & $80 \mathrm{ml}$ & 15 days \\
\hline 2 & Kati Pizichil & Dashmula tail & As pr require & 15 days \\
\hline 3 & Oral & Guggul tiktak kashaya & $20 \mathrm{ml}$ B.D. & 15 days \\
\hline
\end{tabular}

\section{CRITERIA OF ASSESSMENT}

The assessment was done based on subjective parameters. The gradation of signs and symptoms were done (reference article Dr Gaurav sawarkar and Dr Poonam sawarkar mahatma Gandhi Ayurveda college and research centre wardha, March 2016) ${ }^{[7]}$ 
Table 5: Assessment criteria

\begin{tabular}{|c|c|c|}
\hline SR NO & SIGN AND SYMPTOMS & GRADE \\
\hline \multirow[t]{6}{*}{1} & DIFFICULTY IN WALKING & \\
\hline & NO DIFFICULTY & 0 \\
\hline & MILD & 1 \\
\hline & MODERATE & 2 \\
\hline & SEVERE & 3 \\
\hline & VERY SEVERE & 4 \\
\hline \multirow[t]{4}{*}{2} & $\begin{array}{l}\text { PAIN IN HIP JOINT }(B / L) \\
\text { no pain }\end{array}$ & \\
\hline & mild & 0 \\
\hline & moderate & 1 \\
\hline & severe & 2 \\
\hline \multirow[t]{7}{*}{3} & very severe & 3 \\
\hline & RESTRICTED MOVEMENT OF HIP IOINT & 4 \\
\hline & $\begin{array}{l}\text { EXCELLENT-PT are free of pain, can walk as far as they wish without assistance and have at least } \\
75 \% \text { range of motion. }\end{array}$ & 0 \\
\hline & $\begin{array}{l}\text { GOOD- PT has only minimal pain \& ambulate independently with } 1 \text { or } 2 \text { canes. The ROM is over } \\
50 \% \text {. }\end{array}$ & 1 \\
\hline & $\begin{array}{l}\text { FAIR- PT have moderate pain on wt bearing \& can walk only a short distance with assistance. The } \\
\text { ROM is over } 50 \% \text {. }\end{array}$ & 2 \\
\hline & POOR- PT ate confined to a wheelchair with only minimal wt bearing. & 3 \\
\hline & FAILURE- PT have severe pain as rest $\&$ are not able to bear wt & 4 \\
\hline \multirow[t]{6}{*}{4} & LIMPING OF LEG & \\
\hline & walk normally & 0 \\
\hline & slightly lame when walking & 1 \\
\hline & moderate when walking & 2 \\
\hline & severely when walking & 3 \\
\hline & reluctant to rise $\&$ will not walk more than 5 paces & 4 \\
\hline \multirow[t]{6}{*}{5} & STIFFNESS & \\
\hline & no stiffness & 0 \\
\hline & occasionally present & 1 \\
\hline & almost $30 \mathrm{~min}$ & 2 \\
\hline & after long sitting and walking & 3 \\
\hline & whole day and night & 4 \\
\hline
\end{tabular}

Table 6: Result After-Treatment Inpatient A

\begin{tabular}{|l|c|c|}
\hline Sign and symptoms & Before treatment & After treatment \\
\hline Difficulty in walking & 2 & 1 \\
\hline Pain in B/L Hip joint & 2 & 1 \\
\hline Restricted movement of the hip joint & 2 & 1 \\
\hline Limping of leg & 1 & 0 \\
\hline Stiffness & 2 & 1 \\
\hline
\end{tabular}


Table 7: Result After-Treatment Inpatient B

\begin{tabular}{|l|c|c|}
\hline Sign and symptoms & Before treatment & After treatment \\
\hline Difficulty in walking & 4 & 2 \\
\hline Pain in B/L Hip joint & 3 & 2 \\
\hline Restricted movement of the hip joint & 2 & 2 \\
\hline Limping of leg & 3 & 1 \\
\hline Stiffness & 1 & 0 \\
\hline
\end{tabular}

\section{DISCUSSION}

AVN is the collapse or death of bone tissue due to cessation of blood supply of the bone which ultimately leads to loss of joint function, pain in the joints and ultimate damage of the joints. It may be traumatic or non-traumatic. In traumatic injury, blood supply is disturbed due to injury in the femoral artery, the non-traumatic AVN is due to the use of corticosteroids, alcohol or due to due to infection or coagulation defect or due to some autoimmune disorders. In Ayurveda, the sign and symptoms of AVN have resembled Asthimajjagata vata vyadhi. Here the vitiation of dosha and dushya are treated on the line of asthimajjagat vata vikara. Both bahya and abhyantara snehana are the first-line treatment of vata vyadhi, so also Asthimajjagata vata vyadhi the bahya snehana helps in reducing the heaviness, stiffness and increases the blood circulation.

Pizichil is a specialized variety of bahya snehana which are found in more nutrients and nourishing effects in the body. It helps increase the circulation in the affected region, as the medicated oils get deeply absorbed into the skin and strengthing the affected part. Snigdh and guru guna of the sneha nourishes the neurological path of the body, here the vitiated dosha and dushya (i.e. vata dosha, asthi and majja dhatu, snayu and kandara) are elevated due to both bahya and abhyantara snehana. According to physiology vata dosha presides in asthi dhatu so the line of treatment of snehana in vata vyadhi is very helpful to elevate the dosha and normalize the function of vata dosha. Thus, majja basti and pizichil both are very helpful in relieving the symptoms in AVN. In the indication of majja describe that majja is specially used in asthi gata vikara and is dose best snehana and also helpful in bala vriddhi. (Ch. S. 13). ${ }^{[8]}$ Majja given in the form of sneha basti helps in reducing the pain, as basti is the best treatment for vitiated vata dosha. The triglyceride is absorbed by the intestinal epithelial cells, phospholipids are also absorbed directly into the portal blood without digestion due to its poller structure and hydrophilic property. The snehan along with nutrient fluid nourishes the rakta, majja and asthi dhatu. Majja is balya in nature having vata shamak properties and its content which help in the regeneration of asthidhatu.

Dashmoola tail having vatahara balya and brinhana properties help in reducing the pain. In shaman aushadh Guggul tiktak kashaya was administered to the patients. The contents of the kashaya are mostly tikta dravyas (Nimb, Patol, Vasa, Guduchi, Kantkari) ${ }^{[9]}$ and some of its dravya are having deepan pachan and teekshna properties like Shunthi, Marich, Chitrak, Vacha, Pippli, Manjishtha. Tikta dravya is Aakash and Vayu mahabhut dominant drugs hence directly action on asthi and majja dhatu in balances Apana vata. Kashaya also helps in increasing the circulation of the tissue. Thus basti karma (Majja basti) alog with Bahya snehana (Pizichil) and Shamana Kashaya (Guggul tiktak) shows significant improvement in the AVN.

\section{CONCLUSION}

At the end of the therapy majja basti, Pizichil (with Dasmool tail) guggul tiktak kashaya shows remarkable symptomatic relief with increased joint mobility. This result needs to be studied further in more no of patients for a better assessment. 


\section{REFERENCES}

1 NIAMS, October 2015. www.Niams.Nih.Gov>Health info>Osteonecrosis.

2 https//curesearch.org.

3 Isalkar umesh, TNN Oct 15,7:18 IST.

4 Agnivesh charak, charak samhita, Shastri kashinath, Chaturvedi Gorakhnath, Chaukhamba Bharti Academy, Varanasi reprint 2015, page no.782.

5 Agnivesh Charak, Charak Samhita, Tripathi Ravidatta, Shukla Vidhyadhar, Chaukhamba Sanskrit Sansthan, Varanasi Reprint 2015, page no. 701.

6 Agnivesh charak, charak samhita, Tripathi Ravidatta, shukla vidhyadhar, Chaukhamba Sanskrit sansthan, Varanasi reprint 2011, page no. 701.

7 Sawarkar Gaurav, Sawarkar Punam, Avascular necrosis of femoral head, Joinsysmed2016, vol 4(1) page no 46-50.

8 Agnivesh charak, charak samhita, Tripathi Ravidatta, shukla vidhyadhar, Chaukhamba Sanskrit sansthan, Varanasi, reprint 2011, page no. 200.

9 Ibid4.4/7, page no. 67.

\section{Source of Support: Nil Conflict of Interest: None Declared}

How to cite this URL: Bunker Surendra et al: Effect Of Majja Basti And Bahya Snehana (Pizichil) In Avascular Necrosis A Case Report. International Ayurvedic Medical Journal \{online\} 2021 \{cited October 2021\} Available from: http://www.iamj.in/posts/images/upload/2572_2577.pdf 